\title{
Steroids in the Prophylaxis of Fat Embolism Syndrome
}

\section{Shivaprakash SS ${ }^{*}$ and Dr. Ramesh K Sen ${ }^{2}$}

${ }^{1}$ VMMC and Safdarjang Hospital, New Delhi, India

${ }^{2} P G I M E R$, Chandigarh-160012, India

\begin{abstract}
With complex and extensive pharmacological effects, corticosteroids are widely used in many clinical situations. Improving the course and outcome of patients with fat embolism syndrome presents a challenge. By understanding the immune status of a patient, physicians can consider manipulating proinflammatory systems more rationally. In this context, corticosteroids could be a therapeutic tool in the armamentarium against fat embolism syndrome. The inflammatory mechanisms are continuous and cyclic, sometimes causing deterioration or improvement of lung function. Great caution must be taken in clinical situations where administration of corticosteroids is considered contraindicated such as systemic fungal infection, hypersensitivity to the drug, intramuscular injection in idiopathic thrombocytopenia purpura, vaccination with live virus. This article reviews the mechanisms of action of corticosteroids and the results of clinical studies regarding the use of corticosteroids in fat embolism syndrome.
\end{abstract}

Keywords: Thrombocytopenia purpura; Fat Embolism Syndrome; Corticosteroids

\section{Introduction}

Fat Embolism Syndrome (FES) is a serious and potentially life threatening complication associated with post traumatic long bone fractures. It is a complex alteration of homeostasis, manifesting clinically as acute respiratory insufficiency. The reported incidence of FES in different studies has been shown to range from $2 \%$ to $22 \%$ [13]. FES, though uncommon, can be a serious condition with mortality rates ranging from 10 to $36 \%$ [3]. Fat embolism resulting in ARDS carries a poor prognosis with a mortality of $50-90 \%$. Young individuals during the $2^{\text {nd }}$ and $3^{\text {rd }}$ decades of life encountering poly trauma or femur fractures in high velocity accidents are especially at high risk for this complication $[2,3]$. The sub clinical form of FES, presenting with hypoxemia alone, may occur in a majority of trauma patients [3-6].

With FES being such a major problem in trauma patients, a number of ways of preventing the condition have been tried [4]. Heparin, dextran, albumin, hypertonic glucose, aspirin, early fracture stabilization etc. have all been tried with variable results [4]. Maintenance of intravascular volume has been considered important because shock can exacerbate lung injury caused by FES [7].

Steroids have been evaluated as a prophylactic as well as a therapeutic agent in fat embolism in various studies. The purpose of this article is to review the current literature and analyze the present status of steroids in the prophylaxis of fat embolism syndrome.

\section{Clinical Applications of Steroids in Critical Care}

Corticosteroids are administered in physiological doses to reinforce deficient endogenous hormones. In certain pathological status, much larger doses of glucocorticoids are administered with the following aims: decreasing inflammation, suppressing the immune response, affecting the hemopoietic system and metabolism [8].

Steroids have been suggested to be a useful agent in the management of different clinical conditions. Parenteral steroid therapy has been administered in the treatment of acute adrenal insufficiency [9]. It has been used as a second line anti-anaphylactic agent. The principal role of corticosteroids is to attenuate or prevent the "late-phase" reaction, which occurs 6 to $72 \mathrm{~h}$ after the initial anaphylactic episode and is due to recruitment of PMNs and other cells that cause recurrence of symptoms and sign $[10,11]$. Large doses of glucocorticoids given within the first 8 hrs following spinal cord injury improve motor and sensory functions $[12,13]$. It has been used to reduce intracranial pressure in conditions like brain edema, tumours etc [14-20]. There is evidence on the role of steroids as an anti-emetic agent [21], in thyroid storm and also in the control of hypothermia [22-25] (Table 1).

\section{Role of Steroids in Respiratory Insufficiency}

Except for the established role in the management of asthma, the use of corticosteroids in many other forms of respiratory insufficiency remains controversial. Although, it may be helpful for certain specific types of acute respiratory insufficiency with varying success (e.g., acute respiratory distress syndrome, fat embolism syndrome and possibly chronic bronchitis), steroids may worsen other types of respiratory problems (e.g., aspiration pneumonia). Theoretical rationale for the role of steroids includes their ability to decrease pulmonary inflammatory

\begin{tabular}{|c|c|c|c|c|}
\hline Glucocorticoid & $\begin{array}{l}\text { Approximate } \\
\text { equivalent } \\
\text { dose(mg) }\end{array}$ & $\begin{array}{l}\text { Relative anti- } \\
\text { inflammatory } \\
\text { (glucocorticoid) } \\
\text { potency }\end{array}$ & $\begin{array}{l}\text { Relative } \\
\text { mineralocorticoid } \\
\text { (salt retaining) } \\
\text { potency }\end{array}$ & $\begin{array}{l}\text { Biological } \\
\text { half-life(h) }\end{array}$ \\
\hline $\begin{array}{l}\text { Short acting } \\
\text { - Cortisone } \\
\text { - Hydrocortisone }\end{array}$ & $\begin{array}{l}25 \\
20\end{array}$ & $\begin{array}{l}0.8 \\
1\end{array}$ & $\begin{array}{l}2 \\
2\end{array}$ & $\begin{array}{l}8-12 \\
8-12\end{array}$ \\
\hline $\begin{array}{l}\text { Intermediate } \\
\text { acting } \\
\text { - Prednisolone } \\
\text { - Triamcinolone } \\
\text { - Methyl } \\
\text { prednisolone }\end{array}$ & $\begin{array}{l}5 \\
4 \\
4\end{array}$ & $\begin{array}{l}4 \\
5 \\
5\end{array}$ & $\begin{array}{l}1 \\
0 \\
0\end{array}$ & $\begin{array}{ll}18 & -36 \\
18 & -36 \\
18 & -36\end{array}$ \\
\hline $\begin{array}{l}\text { Long acting } \\
\text { - Dexamethasone } \\
\text { - Betamethasone }\end{array}$ & $\begin{array}{l}0.75 \\
0.6-0.75\end{array}$ & $\begin{array}{ll}20 & -30 \\
20 & -30\end{array}$ & $\begin{array}{l}0 \\
0\end{array}$ & $\begin{array}{lll}36 & -54 \\
36 & -54\end{array}$ \\
\hline
\end{tabular}

Table 1: Commonly used Corticosteroid in Peri-operative and Critical Care and comparisons of their Equivalencies, Potencies and Half-life.

*Corresponding author: Dr. Shivaprakash SS, Senior Resident, VMMC and Safdarjang Hospital, New Delhi-110029, India, E-mail: shivushivara@gmail.com

Received August 28, 2012; Published September 28, 2012

Citation: Shivaprakash SS, Sen RK (2012) Steroids in the Prophylaxis of Fat Embolism Syndrome. 1:381. doi:10.4172/scientificreports.381

Copyright: (C) 2012 Shivaprakash SS, et al. This is an open-access article distributed under the terms of the Creative Commons Attribution License, which permits unrestricted use, distribution, and reproduction in any medium, provided the original author and source are credited. 
response, stabilization of lysosomal and capillary membranes, decrease capillary leakage, and prevent platelet and leukocyte agglutination. Other possible beneficial effects include favourable alteration of the Oxy-haemoglobin dissociation curve, improvement in cardiac output, and reduction in pulmonary venous spasm [26-37].

\section{Steroids as a Prophylactic Agent in Fat Embolism Syndrome}

In 1966, Asdbaugh and Petty [38] recommended corticosteroid therapy for treatment of FES and provided laboratory evidence demonstrating its beneficial effect in the experimental animal injected with FFA intravenously. Rokkanen [39] was the first to use steroids prophylactically in an attempt to reduce the incidence of FES following massive trauma. Kreis [40] demonstrated that corticosteroids improved oxygenation and decreased the pathologic changes seen on pulmonary biopsies in experimental animals. Gregory [41] showed that the steroids must be given prior to the free fatty acid injection to be of benefit (Table 2).

Alho et al. [42] had studied the role of intravenous methyl prednisolone sodium succinate in the prophylaxis of fat embolism syndrome in the year 1978. He had included a total of 60 patients who had suffered atleast two fractures (pelvic, femoral or tibial fractures). The mean age of the patients in this study was 35.2 years (Range 16$83)$. He used a relatively high dose of steroids $(10 \mathrm{mg} / \mathrm{kg}$ iv every 8 hours, total of 3 doses). He defined hypoxemia as $\mathrm{paO}_{2}$ of less than $60 \mathrm{mmHg}$. There was an incidence of $48.4 \%$ hypoxemia in the control group (who were not given the steroid prophylaxis). The incidence of hypoxemia in the steroid treated group was significantly less (6.9\%). Alho had defined fat embolism syndrome as a combination of hypoxemia, bilateral "snow storm" infiltrations of the lungs, petechial rash, mental disturbances, pyrexia, anemia and thrombocytopenia. These parameters were monitored for a period of 5 days. There was also a significant decrease in the incidence of fat embolism syndrome (13\% in the control population as against $3 \%$ in the methyl prednisolone treated group).

A similar study by Stoltenberg and Gustilo [43] in 1979 had included 64 patients with fractures of femur or tibia. The mean age group in this population was 29.96 and a dose of $1 \mathrm{~g}$ of steroids was administered 8 hourly (total 3 doses). Hypoxemia was defined as $\mathrm{paO}_{2}<70 \mathrm{~mm} \mathrm{Hg}$. There was a significant decrease in the incidence of hypoxemia and fat embolism syndrome (39\% hypoxemia in the control population as against $15 \%$ in the steroid treated population). There was $8 \%$ incidence of fat embolism in the control population. However, none of the patients in the steroid treated group had developed fat embolism. The criteria for defining fat embolism syndrome were, however, not mentioned in this article.

Lindeque et al. [44], in 1987, used steroids in the dosage of $30 \mathrm{mg} /$ $\mathrm{kg}$ intravenously at admission followed by another dose 4 hours later. 62 patients with one or more diaphyseal fractures of the lower limb with a mean age of 27.5 years were included in the study. Lindeque had defined fat embolism by the following criteria:

1. A sustained $\mathrm{PaO}_{2}$ of less than $60 \mathrm{mmHg}$.

2. A sustained $\mathrm{PaCO}_{2}$ of more than $55 \mathrm{mmHg}$ or a $\mathrm{pH}$ of less than 7.3 .

3. A sustained respiratory rate of more than 35 breaths per minute even after adequate sedation.
4. Increased work of breathing - dyspnoea, the use of accessory respiratory muscles, and tachycardia - combined with anxiety.

A patient showing at least one of the above criteria was judged to have developed FES. There was significant decrease in the incidence of fat embolism syndrome and hypoxemia in his patients. (hypoxemia of $57 \%$ in control group v/s $22 \%$ in steroid treated group and fat embolism of $46 \%$ in control population v/s $11.11 \%$ in steroid treated population).

Schonfeld et al. [45] in 1983, had studied 55 patients with femoral or tibial fractures with a mean age of 34.95 years. Steroids were administered in the dose of $7.5 \mathrm{mg} / \mathrm{kg} 6$ hourly (total 12 doses). Schonfeld had defined fat embolism by the Shier's fat embolism index score.

A score of more than 5 was required to diagnose fat embolism syndrome. Hypoxemia did not reduce significantly in this study following steroids administration (14.4\% in controls versus $10 \%$ in steroid treated group). However, the administration of steroids significantly reduced the incidence of fat embolism syndrome (22\% in the control group as against $0 \%$ in the steroid treated group).

Kallenbach et al. [46], in the year 1987, had studied 82 patients with one or more diaphyseal fractures of the lower limb with a mean age of 24 years. A low dose steroid prophylaxis of $1.5 \mathrm{mg} / \mathrm{kg}$ body weight 8 hourly for a total of 6 doses was administered. The diagnosis of fat embolism was based only on the appearance of multiple obvious petechial hemorrhages associated with atleast one of the following: confusion, arterial hypoxemia, X-ray evidence of diffuse pulmonary infiltrate. One out of the 41 cases in study group and 10 out of 42 in controls had developed FES (Chi square p 0.01). Hypoxemia was defined by $\mathrm{paO}_{2}$ less than $60 \mathrm{mmHg}$ was, however, detected in 22 of the cases and 33 of the controls ( $p$ less than 0.05).

Babalis et al. [47] in the year 2004 had studied 87 patients with isolated femoral or tibial fracture without lesions in other organs or pre-existing chronic diseases. The mean age of these patients was 22.4 years. Intravenous methyl prednisolone sodium succinate in the dose of $1 \mathrm{mg} / \mathrm{kg} 8$ hourly for a total of 6 doses was administered. They had defined fat embolism syndrome by the Shier's fat embolism index. They did not observe a significant reduction in the incidence of FES (15\% in controls as against $2.1 \%$ in cases), although they had a significant reduction in the incidence of hypoxemia (32\% with hypoxemia in controls with no hypoxemic patient in steroid treated population).

Thus, all the studies have shown a positive effect of steroids as a prophylactic agent in fat embolism syndrome. The least dose that has been used so far is $6 \mathrm{mg} / \mathrm{kg}$ body weight in 6 divided doses. There have been no further studies on steroid prophylaxis of FES using the same minimal dose.

\section{Mechanism of Action of Steroids}

The mechanism of action of steroids has not yet been ascertained. They possibly act through the inhibition of plasma complement

\begin{tabular}{|c|c|}
\hline Condition & Score \\
\hline Petechiae & 5 \\
\hline Diffuse alveolar infiltrates & 4 \\
\hline Hypoxemia $($ paO2<9, 3kPa) & 3 \\
\hline Confusion & 1 \\
\hline Fever $>38$ degree & 1 \\
\hline Heart rate $>120 /$ min & 1 \\
\hline Respiratory rate $>30 /$ min & 1 \\
\hline
\end{tabular}

Table 2: Shier's Fat Embolism Index Score. 


\begin{tabular}{|c|c|c|c|c|c|}
\hline Authors & Number and characteristics of the patients & Age (years) & Active treatment & $\begin{array}{l}\text { FES in study } \\
\text { group }\end{array}$ & $\begin{array}{l}\text { FES in } \\
\text { control group }\end{array}$ \\
\hline $\begin{array}{l}\text { Stoltenberg et } \\
\text { al. [43] }\end{array}$ & $\begin{array}{l}64 \text { patients. Femoral or tibial fracture without lesions in other } \\
\text { organs, without COPD or DM. Age below } 65 \text { years. }\end{array}$ & Mean, 29 & $\begin{array}{l}\text { Methylprednisolone } 1 \mathrm{~g} \text { every } 8 \text { hours; } \\
\text { total of } 3 \text { doses. }\end{array}$ & $0 \%$ & $8 \%$ \\
\hline $\begin{array}{l}\text { Schonfeld et al. } \\
{[45]}\end{array}$ & $\begin{array}{l}62 \text { patients. One or more diaphyseal fractures of a lower limb. } \\
\text { Without accompanying lesions in other organs. }\end{array}$ & $\begin{array}{c}15-87 \\
\text { Mean-34.95 }\end{array}$ & $\begin{array}{l}\text { Methylprednisolone } 7.5 \mathrm{mg} / \mathrm{kg} \text { every } 6 \\
\text { hours; total of } 12 \text { doses. }\end{array}$ & $0 \%$ & $22 \%$ \\
\hline $\begin{array}{l}\text { Lindeque et al. } \\
{[44]}\end{array}$ & $\begin{array}{l}55 \text { patients. Femoral or tibial fracture with or without laceration } \\
\text { of soft tissue. } \\
\text { Without lesions in other organs or pre-existing pulmonary or } \\
\text { cardiac diseases. }\end{array}$ & $\begin{array}{c}16-54 \\
\text { Mean-27.5 }\end{array}$ & $\begin{array}{l}\text { Methylprednisolone } 30 \mathrm{mg} / \mathrm{kg} \text { IV at } \\
\text { admission and one dose repeated } 4 \\
\text { hours later. }\end{array}$ & $11.11 \%$ & $46 \%$ \\
\hline $\begin{array}{l}\text { Kallenbach et al. } \\
{[46]}\end{array}$ & $\begin{array}{l}82 \text { patients. One or more diaphyseal fractures of a lower limb. } \\
\text { Without lesions in other organs or pre-existing pulmonary or } \\
\text { cardiac diseases. }\end{array}$ & $\begin{array}{c}14-45 \\
\text { Mean-24 }\end{array}$ & $\begin{array}{l}\text { Methylprednisolone } 1.5 \mathrm{mg} / \mathrm{kg} \text { IV every } \\
8 \text { hours; total of } 6 \text { doses. }\end{array}$ & $2.4 \%$ & $23 \%$ \\
\hline Babalis et al. [47] & $\begin{array}{l}87 \text { patients with isolated femoral or tibial fracture. Without } \\
\text { lesions in other organs or pre-existing chronic diseases. }\end{array}$ & \begin{tabular}{c|c}
$18-28$ \\
Mean-22.4
\end{tabular} & $\begin{array}{l}\text { Methylprednisolone } 1 \mathrm{mg} / \mathrm{kg} \text { IV every } 8 \\
\text { hours; total of } 5 \text { doses. }\end{array}$ & $2.1 \%$ & $15 \%$ \\
\hline
\end{tabular}

IV: intravenous; COPD: chronic obstructive pulmonary disease; and DM: diabetes mellitus

Table 3: Characteristics of the studies.

activation; decreasing the WBC aggregation and release of toxins; decreasing the capillary leakage [48] and protecting cell membranes [42] like platelet and endothelium.

The work of Peltier, Allardyce, Meek, Kerstall, Hausberger, Fonte and Collins has suggested the mechanical-chemical theory of fat embolism. Lipoprotein lipase from the lungs hydrolyses the neutral triglycerides to glycerol and free fatty acids. The inflammation caused by these free fatty acids is responsible for the pathological changes occurring in the lungs [43].

Corticosteroids are most likely of benefit by decreasing the endothelial damage caused by the liberated free fatty acids. Another possible mechanism suggested by Stoltenberg and Gustilo has been by the elevation of serum glucose through gluconeogenesis, which in turn, improved oxygenation [43].

\section{Complications of Steroids}

Even with higher doses of steroids, most of the studies had not shown any steroid related complications except for the Clostridial infection in one patient with insulin dependent diabetes mellitus in the study by Kallenbach et al. [46]. However, all the authors had expressed their suspicions regarding the possibilities of complications following steroid prophylaxis in trauma situations. The authors had reported hypothalamic-pituitary-adrenal insufficiency, hyperglycemia, renal complications like hypokalemia, fluid volume shifts, impaired wound healing, post-operative infections, amenorrhea, intrauterine growth retardation in females of reproductive age group, infertility, myopathy, neuropsychiatric manifestations, cardiac complications like hypertension, premature atherosclerosis, ophthalmological complications like cataract, glaucoma, pseudotumor cerebri, gastrointestinal side effects like peptic ulcer disease, steatohepatitis, increased risk of infections, osteonecrosis of femoral head etc. [4951] as the known complications of steroid administration. These side effects, however, usually occur when larger doses are used for longer duration.

\section{Conclusions and Future Trends}

Of the multiple prophylactic agents tried thus far in fat embolism syndrome, steroids have been shown to be quite successful. The previous studies have tried different doses of steroids ranging from as little as $6 \mathrm{mg} / \mathrm{kg}$ and have shown varying degrees of response. Methyl prednisolone sodium succinate has been used as the intravenously administered form of steroid in these studies (Table 3).
The doses as high as $3 \mathrm{~g}$ of steroids (Stoltenberg and Gustilo), though, had a significant reduction in fat embolism, might carry a greater risk of complications. The lowest dose used by Babalis et al. had an insignificant reduction of fat embolism syndrome, although, the incidence of hypoxemia was significantly reduced.

Thus, the dose that strikes the exact balance between benefits and possible risks has not been, yet, established. The protocol suggesting the exact group of patients in whom the benefits of steroid prophylaxis will outweigh the possible complications has also not been developed. Other routes of local steroid administration like inhalational steroids are also under study. This may reduce the unnecessary systemic complications with maximum local benefit.

\section{References}

1. Sproule BJ, Brady JL, Gilbert J (1964) Studies on the syndrome of fat embolization. Can Med Assoc J 90: 1243-1247.

2. Wertzberger JL, Peltier LF (1968) Fat embolism: the importance of arterial hypoxia. Surgery 63: 626-629.

3. Sturm JA, Lewis FR, Trentz O, Oestern HJ, Hemgelman G, et al. (1979) Cardiopulmonary parameter and prognosis after severe multipla trauma. J Trauma 19: 305-318.

4. Hutchins PM, Macnicol MF (1985) Pulmonary insufficiency after long bone fractures. Absence of circulating fat or significant immunodepression. J Bone Joint Surg Br 67: 835-839.

5. Levy D (1990) The fat embolism syndrome. A review. Clin Orthop Relat Res 261: 281-286.

6. Gossling HR, Pellegrini VD (1982) Fat embolism syndrome. A review of the pathophysiology and physiological basis of treatment. Clin Orthop Relat Res 165: 68-82.

7. Robinson CM (2001) Current concepts of respiratory insufficiency syndromes after fracture. J Bone Joint Surg $\mathrm{Br}$ 83: 781-791.

8. McEvoy GK, Miller JL, Litvak K (2002) AHFS Drug Information. Bethesda: American Society of Hospital Pharmacists 2908-2938.

9. Grossman A (1992) What is the cause of Cushing's disease? Clin Endocrinol (oxf) 6: 451-452.

10. Chamberlain $D$ (1999) Emergency medical treatment of anaphylactic reactions Project Team of the Resuscitation Council (UK). J Accid Emerg Med 16: 243247

11. (2000) Guidelines 2000 for Cardiopulmonary Resuscitation and Emergency Cardiovascular Care. Part11: neonatal resuscitation. The American Heart Associationin collaboration with the International Liaison Committee on Resuscitation. Circulation 102: 343-357.

12. Ducker TB, Spengler DM, Balderston R, Keller T, Benson D, et al. (1990) Spinal cord injury and glucocortical steroid therapy: Good news and bad. $J$ Spinal Disord 3: 433-435. 
13. (1990) A randomized, controlled trial of methylprednisolone or naloxone in the treatment of acute spinal-cord injury. N Engl J Med 323: 1207-1209.

14. Marik P, ChenK, Varon J, Fromm R Jr, Sternbach GL (1999) Management of increased intracranial pressure: A review for clinicians. J Emerg Med 17 711-719.

15. Alderson P, Roberts I (1997) Corticosteroids in acute traumatic brain injury: systematic review of randomised controlled trials. BMJ 314: 1855-1859.

16. Matta BF, Menon DK, Turner JM (2000) Textbook of Neuroanesthesia and Critical Care. Greenwich Medical Media LTD 311, London.

17. Chumas P, Condon B, Oluoch-Olunya D, Griffiths S, Hadley D, et al. (1997) Early changes in peritumorous oedema and contralateral white matter after dexamethasone: A study using proton magnetic resonance spectroscopy. J Neurol Neurosurg Psychiatry 62: 590-595.

18. Skjoeth J, Bjerre PK (1997) Effect of glucocorticoids on ICP in patients with a cerebral tumour. Acta Neurol Scand 96: 167-170.

19. Greenberg MS (1997) Handbook of Neurosurgery (4thedn) Greenberg Graphics Inc, Florida, pp. 241-242.

20. Greenberg MS (1997) Handbook of Neurosurgery (4thedn) Greenberg Graphics Inc, Florida, pp. 625.

21. Aapro MS, Alberts DS (1981) Dexamethasone as an antiemetic in patients treated with cisplatin. N Engl J Med 305: 520.

22. Burch HB, Wartofsky L (1993) Life-threatening thyrotoxicosis. Thyroid storm. Endocrinol Metab Clin North Am 22: 263-277.

23. Felicetta JV, Green WL, Goodner CJ (1980) Decreased adrenal responsiveness in hypothermic patients. J Clin Endocrinol Metab 50: 93-97.

24. Felicetta JV, Green WL (1979) Hypothermia and adrenocortical function. Ann Int Med 90: 855.

25. Kollef MH, Schuster DP (1995) The acute respiratory distress syndrome. N Engl J Med 332: 27-37.

26. Biffl WL, Moore FA, Moore EE, Haenel JB, McIntyre RC, et al. (1995) Are corticosteroids salvage therapy for refractory acute respiratory distress syndrome? Am J Surg 170: 591-596.

27. Brun-Buisson C, Brochard L (1998) Corticosteroid therapy in acute respiratory distress syndrome: better late than never? JAMA 280: 182-183.

28. Hudson LD (1995) New therapies for ARDS. Chest 108: 79s-91s.

29. Meduri GU, Headley AS, Golden E, Carson SJ, Umberger RA, et al. (1998) Effect of prolonged methylprednisolone therapy in unresolving acute respiratory distress syndrome: Arandomized controlled trial. JAMA 280: 159-165.

30. Johnson MJ, Lucas GL (1996) Fat embolism syndrome. Orthopedics 19: 41-49.

31. Kallenbach J, Lewis M, Zaltzman M, Feldman C, Orford A, et al. (1987) "Lowdose" corticosteroid prophylaxis against fat embolism. J Trauma 27: 11731176.

32. Richards RR (1997) Fat embolism syndrome. Can J Surg 40: 334-349.

33. Van Besouw JP, Hinds CJ (1989) Fat embolism syndrome. Br J Hosp Med 42: 304-311.
34. Callahan CM, DittusRS, Katz BP (1991) Oral corticosteroid therapy for patients with stable chronic obstructive pulmonary disease. Ann Intern Med 114: 216 223.

35. Niewoehner DE, Erbland ML, Deupree RH, Collins D, Gross NJ, et al. (1999) Effect of systemic glucocorticoids on exacerbations of chronic obstructive pulmonary disease. N Engl J Med 340: 1941-1947.

36. Niewoehner DE (1999) Systemic corticosteroids for chronic obstructive pulmonary disease: benefits and risks. Monaldi Arch Chest Dis 54: 422-426.

37. Ryan DW (1984) Pulmonary aspiration: High dose steroids should be abandoned. Br Med J 289: 51.

38. Ashbaugh DG, Petty TL (1966) The use of corticosteroids in the treatment of respiratory failure associated with massive fat embolism. Surg Gynecol Obstet 123: $493-500$

39. Rokkanen P, Alho A, Avikainen V, Karaharju E, Kataja J, et al. (1974) The efficacy of corticosteroids in severe trauma. Surg Gynecol Obstet 138: 69-73

40. Kreis WR, Lindenauer SM, Dent TL (1973) Corticosteroids in experimental fat embolization. J Surg Res 14: 238-246.

41. Gregory CF (1974) Unpublished paper presented at the 1974 Ortho-Trauma Seminar. Hennepin County Medical Center, Minneapolis, Minnesota.

42. Alho A, Saikku K, Eerola P, Koskinen M, Hamalainen M (1978) Corticosteroids in patients with a high risk of fat embolism syndrome. Surg Gynecol Obste 147: 358-362.

43. Stoltenberg JJ, Gustilo RB (1979) The use of methylprednisolone and hypertonic glucose in the prophylaxis of fat embolism syndrome. Clin Orthop Relat Res 143: 211-221.

44. Lindeque BG, Schoeman HS, Dommisse GF, Boeyens MC, Vlok AL (1987) Fa embolism and the fat embolism syndrome. A double-blind therapeutic study. $J$ Bone Joint Surg Br. 69: 128-131.

45. Schonfeld SA, Ploysongsang Y, DiLisio R, Crissman JD, Miller E, et al. (1983) Fat embolism prophylaxis with corticosteroids. A prospective study in high-risk patients. Ann Intern Med 99: 438-443.

46. Kallenbach J, Lewis M, Zaltzman M, Feldman C, Orford A, et al. (1987) 'Low dose'corticosteroid prophylaxis against fat embolism. J Trauma 27: 1173-1176.

47. Babalis GA, Yiannakopoulos CK, Karliaftis K, Antonogiannakis E (2004) Prevention of posttraumatic hypoxaemia in isolated lower limb fractures with minimal prophylactic dose of corticosteroids. J Injury 35: 309-317.

48. Shier MR, Wilson RF (1980) Fat embolism syndrome: traumatic coagulopathy with respiratory distress. Surg Annu 12: 139-168.

49. Salerno A, Hermann R (2006) Efficacy and safety of steroid use for postoperative pain relief. Update and review of the medical literature. $\mathrm{J}$ Bone Joint Surg 88: 1361-1372.

50. Britt RC, Devine A, Swallen KC, Weireter LJ, Collins JN, et al. (2006) Corticosteroid use in the intensive care unit: at what cost? Arch Surg 141: 145149.

51. Barber D, Ghorbani P, Wenker O (1997) Supplemental Steroids in the operating room: a Review of the Literature. The internet J Anesthesiology 1. 